\title{
The familial occurrence of the Kartagener triad in Jamaica
}

\author{
Gilbert H. Aarons \\ M.B., B.S.(Lond.)
}

\author{
IsAaC J. Powell \\ B.S.(U. of Mich.), M.S.(Howard)
}

\author{
Department of Medicine, \\ University Hospital of the West Indies
}

THE OCCURRENCE of sinusitis, bronchiectasis and situs inversus in the same patient was first noted by Siewart in 1903. Oeri made similar observations in 1909. However, Kartagener (1933) was the first to conclude that the occurrence of sinusitis and bronchiectasis was more common in patients with situs inversus than in others. He reported four cases in 1933 and seven cases in 1935 (Kartagener \& Horlacher, 1935). Since then the triad has acquired his name. Kartagener \& Stucki (1962) reviewed 334 reported cases and suggested that the incidence of the syndrome is about $1: 40,000$.

Gunther (1923) first described a family in which two siblings of four presented with Kartagener's syndrome. Subsequently, at least seven families have been reported. Many authors have found that there is a higher incidence in male than in female siblings (Cockayne, 1938; Logan, Abbott \& Hatcher, 1965), that in affected families neither of the parents need show any evidence of the triad, and that features of the syndrome can occur in various combinations within the same family (Bergstrom et al., 1950; Overholt \& Bauman, 1958).

This report describes a family in which two siblings exhibit the complete Kartagener triad, another sibling showing sinusitis alone. The other three siblings in the family are clinically normal and the parents, who are not consanguinous, show no evidence of abnormality or disease (Fig. 1).

\section{Case reports}

Case No. 1

C.J., aged 21, gave a history of chronic cough and cold together with nasal stuffiness and headaches since childhood; he had one episode of haemoptysis and was a mouth-breather during his youth. He had no difficulty in hearing and gave no history of allergy.

Examination revealed coarse rhonchi in his lungs, nasal polyposis, dextrocardia and hepatic dullness
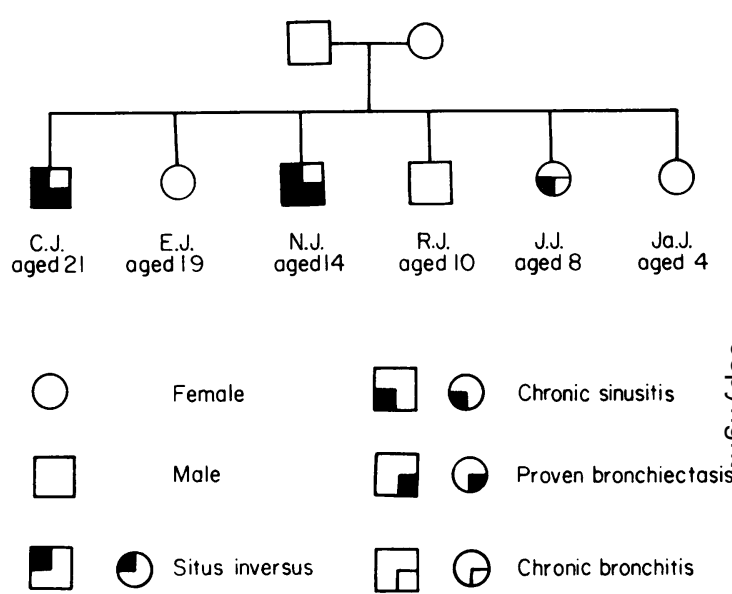

FIG. 1. Family pedigree.

on the left side of his abdomen. There was no cyanosis or clubbing.

Investigations: ECG showed true dextrocardia; Mantoux test $1: 1000$ positive; culture of purulent sputum revealed a mixture of normal upper respiratory tract flora; protein electrophoresis was normal; chest X-ray showed dextrocardia with the gastric bubble on the right; skull X-rays revealed hypoplastic sinuses and mastoids with signs of chronic inflammation; bronchogram showed mild bronchiectasis of the cylindrical type; respiratory function tests showed a forced vital capacity of $2850 \mathrm{ml}$, $\mathrm{FEV}_{1} 2000 \mathrm{ml}$; haemoglobin electrophoresis was $A C$; auditory examination was normal.

\section{Case No. 2}

N.J., aged 14, gave a history of chronic cough and cold since early childhood; he was a mouth-breather and was hard of hearing. He gave no history of haemoptysis nor of allergy.

Examination revealed coarse rhonchi in his lungs; his cardiac apex beat on the right side of his chest 
and liver dullness on the left side of his abdomen. There was no cyanosis or clubbing.

Investigations: ECG showed true dextrocardia; Mantoux test was negative; purulent sputum grew Pseudomonas pyocyanea; protein electrophoresis was normal; chest X-ray showed dextrocardia with the gastric bubble on the right; skull X-rays revealed hypoplastic sinuses and mastoids with signs of chronic inflammation.

The right bronchogram showed a typical left bronchial tree without any bronchial abnormality. The left bronchogram showed a right bronchial tree pattern with the following abnormalities: (1) a high division of the main stem bronchus; (2) cystic bronchiectasis of the medial basal segment; and (3) a separate origin of this affected segment from the main stem bronchus. Respiratory function tests showed a forced vital capacity of $2208 \mathrm{ml}$, FEV $1380 \mathrm{ml}$. Haemoglobin electrophoresis was AC. Otoscopy revealed a perforation of his right ear drum and audiograms showed moderate impairment of hearing in both ears.

\section{Case No. 3}

J.J., aged 8, gave a history of chronic cough and cold together with nasal stuffiness and headaches; she was a mouth-breather and had difficulty in hearing. She gave no history of haemoptysis or allergy.

Examination revealed coarse rhonchi in her chest but no signs of dextrocardia or of situs inversus. Her hearing was mildly impaired. There was no cyanosis or clubbing.

Investigations: ECG was normal; Mantoux test was negative; sputum grew no pathogens; protein electrophoresis was normal; chest X-ray was normal; skull X-ray showed hypoplastic sinuses and mastoids with signs of chronic inflammation. A bronchogram was not done. Respiratory function tests revealed a forced vital capacity of $925 \mathrm{ml}, \mathrm{FEV}_{1} 800 \mathrm{ml}$. Haemoglobin electrophoresis was AC. Audiogram showed a mild hearing loss in both ears.

\section{Discussion}

Kartagener's syndrome may be a congenital abnormality (Schoemperlen \& Carey, 1968) due to a recessive gene with a pleiotropic effect, i.e. a single genetic abnormality affecting several organ systems (Holmes, Blennerhassett \& Austen, 1968). This theory is supported by our findings where three siblings in a sibship of six were affected. Similar findings were reported by Campbell (1963). In the Kartagener syndrome the entire respiratory system is affected, and there is usually co-existent disease of the paranasal sinuses, the middle ears and the bronchi.

Whereas environmental factors during the development of the embryo may contribute to the formation of bronchiectasis (Adams \& Churchill, 1937), the bronchiectasis seen in this syndrome is usually of the tubular post-infective type rather than of the saccular congenital form (Overholt \& Bauman, 1958); and although a congenital defect may be present in the bronchial wall (Karani, 1952) microscopy reveals the features of chronic infection but no features pathognomonic of the syndrome. Other possible explanations for the development of bronchiectasis include the formation of immature bronchial pouches, failure of proper pulmonary expansion after birth, occlusion of certain bronchi by the right-sided heart, and as a result of chronic upper respiratory tract infection. However, although all these factors may be contributory, no direct causal relationship has yet been established. Two of the affected patients in this report showed radiological evidence of bronchiectasis.

Abnormalities of the bronchial tree have been reported (Mayo, 1961) and here we have seen evidence of this in one patient. Although many studies have shown a high incidence of cardiac, splenic, vertebral and visceral abnormalities associated with situs inversus none was seen in the patients studied.

The patients were all receiving conservative medical treatment: antibiotics, breathing exercises and postural drainage. Surgery, which is of value in some cases of Kartagener's syndrome (Chang, 1963), has not yet been considered.

We know of no previous reports of an association of AC haemoglobinopathy with Kartagener's syndrome.

\section{Acknowledgments}

It is a pleasure to record our thanks to the following members of staff of the University Hospital of the West Indies: Professor K. L. Stuart, for his helpful advice during the preparation of this paper and for his permission to publish clinical details of these patients; Dr E. M. Bateson and Dr N. Moule, for interpreting the X-rays; Mr R. Simons, for otorhinolaryngological advice.

\section{References}

Adams, R. \& Churchill, E.D. (1937) Situs inversus, sinusitis and bronchiectasis. J. thoracic Surg. 7, 206.

Bergstrom, W.H., Cook, C.D., Scannell, J. \& Berenberg, W. (1950) Situs inversus, bronchiectasis and sinusitis; report of a family with two cases of Kartagener's triad and two additional cases of bronchiectasis among six siblings. Pediatrics, 6, 573.

Campbell, M. (1963) The mode of inheritance in isolated laevocardia and dextrocardia and situs inversus. Brit. Heart J. 25, 803.

ChANG, R.K.H. (1962) Kartagener's triad. Review of surgically treated cases and report of case treated by bilateral multiple segmental resection. J. thoracic cardiovasc. Surg. 43, 127.

Cockayne, E.A. (1938) The genetics of transposition of the viscera. Quart. J. Med. 7, 479.

GunTHER, H. (1923) Die biologische Bedetung der Inversionen Biol. Zbl. 43, 175. 
Holmes, L.B., Blennerhassett, J.B. \& Austen, K.F. (1968) A Reappraisal of Kartagener's Syndrome. Amer. J. med. Sci. 255, 13.

KARANI, S. (1952) Kartagener's Syndrome. Brit. med. J. 2, 74.

Kartagener, M. (1933) Zur Pathogenese der Bronchiectasien. I. Mittleilung: Bronchiectasien bei Situs Viscerum Inversus. Beitr. Klin. Tuberk. 38, 489.

Kartagener, M., and Horlacher, A. (1935) Bronchiectasien bei Situs Viscerum Inversus. Schweiz. med. Wschr. 65, 782.

Kartagener, M. \& Stucki, P. (1962) Bronchiectasis with Situs Inversus. Arch. Pediat. 79, 193.
Logan, W.K., Abbott, O.A. \& HATcher, C.R., JR (1965) Kartagener's triad. Dis. Chest. 48, 613.

MAYo, P. (1961) Kartagener's syndrome. J. thoracic cardiovasc. Surg. 42, 39.

OERI, R. (1909) Zur Kaswinstik des Situs Viscerum Inversus Totalis. Z. Path. Wissensch. 3, 393.

OVERHOLT, E.L. \& BAUMAN, D.F. (1958) Variants of Kartagener's syndrome in the same family. Ann. intern. Med. 48, 574.

SChOEMPERlen, C.B. \& CAREY, S.L. (1963) Kartagener's syndrome. Amer. Rev. resp. Dis. 88, 698.

SIEWART, A.R. (1903) Uber einem Fall von Bronchiectasis bei sinem Patientem mit Situs Inversus Viscerum. Berl. klin. Wschr. 41, 139.

\title{
Insidious rheumatic carditis and athletic activities
}

\author{
Luis VASSALlo \\ B.Sc., M.D., M.R.C.P., M.R.C.P.(Ed.), M.R.C.P.(Glasg.) \\ Department of Medicine, Royal University of Malta, \\ and St Luke's Hospital, Pietá, Malta
}

ONE IS often unable to elicit any past history of definite acute rheumatic fever, or one suggesting streptococcal infection, from a patient with established rheumatic valvular heart disease. This failure to elicit a positive past history may be attributed, understandably, to the inherent defects of retrospective analysis and the fallibility of human memory. It is not sufficiently appreciated in general medical circles that acute rheumatic carditis may be present not only with little or no symptoms, but moreover in the presence of full physical activity and apparent good health. Though the insidiousness of acute rheumatic carditis in children is well documented, its co-existence with no impairment of athletic activities in a young adult does not appear to have been described before.

\section{Case report}

A young Maltese male of average build, aged 20 years old, was brought for a check-up by his mother as she felt he had been overstraining himself physically during the previous 2 months.

He had no specific complaints but admitted to mild general tiredness. There were no aches or pains. He had suffered from a mild afebrile sore throat a few weeks before. There was no past history of rheumatic fever. He attributed his mild tiredness to excessive physical activity. He had a keen interest in sport and for the past few months had been playing football and basketball regularly twice weekly. His physical activities had been particularly strenuous during the previous week as in addition to athletics, he had been dancing nightly till 03.00 hours because of the carnival festivities. The day before, he had participated in a game of basketball and hado scored 20 points; on the previous day to this he had played a full game of football as centre forward. $\mathrm{He}$ had also started training for cross country running.

On examination, the pulse was $80 / \mathrm{min}$, with occasional missed beats. The jugular venous pulse and pressure were normal. The cardiac apex was not displaced and was of normal character. No murmurs were present at the apex or over the base of the heart. BP $120 / 80 \mathrm{mmHg}$. There were no other abnormalities on general examination.

In order to reassure the patient's mother and at the same time to establish the innocence of the cardiac irregularity, an electrocardiogram was carried out the next day (11 March 1967). The ECG, to one's surprise, showed partial AV block of the Wenckebach type; the shortest PR interval being $0.22 \mathrm{sec}$, increasing in the next beat to $0.26 \mathrm{sec}$ and followed by ventricular asystole on the third beat, with the PR interval returning to $0.22 \mathrm{sec}$ in the next beat. There were no obvious vector abnormalities nor any evidence of ventricular hypertrophy. The erythrocyte sedimentation rate was $90 \mathrm{~mm} / \mathrm{hr}$. The patient was admitted to hospital and started on a 10-day course of crystalline penicillin followed by Penadur LA 1,200,000 units i.m. once every 3 weeks. He was also started on acetylsalicylic acid $15 \mathrm{~g}$ orally every $4 \mathrm{hr}$, with the omission of one night dose. Investigations included: $\mathrm{Hb} 12.7 \mathrm{~g} / 100 \mathrm{ml}$; 